OPEN ACCESS

Edited by:

María Serrano,

Miguel Hernández University of Elche,

Spain

Reviewed by:

Pradeep Kumar,

North Eastern Regional Institute of Science and Technology, India

Ghulam Khaliq,

Lasbela University of Agriculture, Water and Marine Sciences, Pakistan

Simona Marianna Sanzani, International Centre for Advanced Mediterranean Agronomic Studies,

Periyar Selvam Sellamuthu,

SRM Institute of Science and Technology, India

*Correspondence: Gianfranco Romanazzi g.romanazzi@univpm.it

†These authors have contributed equally to this work

Specialty section: This article was submitted to Crop and Product Physiology, a section of the journal

Frontiers in Plant Science

Received: 01 September 2021

Accepted: 05 October 2021

Published: 11 November 2021

Citation:

Landi L, Peralta-Ruiz Y, Chaves-López C and Romanazzi G (2021) Chitosan Coating Enriched With Ruta graveolens L. Essential OI

Reduces Postharvest Anthracnose

of Papaya (Carica papaya L.) and Modulates Defense-Related Gene Expression

Front. Plant Sci. 12:765806. doi: 10.3389/fp/s.2021.765806

\section{Chitosan Coating Enriched With Ruta graveolens L. Essential Oil Reduces Postharvest Anthracnose of Papaya (Carica papaya L.) and Modulates Defense-Related Gene Expression}

\author{
Lucia Landi1†, Yeimmy Peralta-Ruiz ${ }^{2,3+}$, Clemencia Chaves-López² and \\ Gianfranco Romanazzi ${ }^{1 *}$ \\ 'Department of Agricultural, Food and Environmental Sciences, Marche Polytechnic University, Ancona, Italy, ${ }^{2}$ Faculty \\ of Bioscience and Technology for Food, Agriculture and Environment, University of Teramo, Teramo, Italy, ${ }^{3}$ Facultad \\ de Ingeniería, Programa de Ingeniería Agroindustrial, Universidad del Atlántico, Puerto Colombia, Colombia
}

Anthracnose of papaya (Carica papaya L.) caused by the fungus Colletotrichum spp. is one of the most economically important postharvest diseases. Coating with chitosan (CS) and Ruta graveolens essential oil (REO) might represent a novel eco-friendly method to prevent postharvest anthracnose infection. These compounds show both antimicrobial and eliciting activities, although the molecular mechanisms in papaya have not been investigated to date. In this study, the effectiveness of CS and REO alone and combined (CS-REO) on postharvest anthracnose of papaya fruit during storage were investigated, along with the expression of selected genes involved in plant defense mechanisms. Anthracnose incidence was reduced with CS, REO, and CS-REO emulsions after 9 days storage at $25^{\circ} \mathrm{C}$, by 8,21 , and $37 \%$, respectively, with disease severity reduced by 22,29 , and $44 \%$, respectively. Thus, McKinney's decay index was reduced by 22,30 , and $44 \%$, respectively. A protocol based on reverse transcription quantitative real-time PCR (RT-qPCR) was validated for 17 papaya target genes linked to signaling pathways that regulate plant defense, pathogenesis-related protein, cell walldegrading enzymes, oxidative stress, abiotic stress, and the phenylpropanoid pathway. CS induced gene upregulation mainly at $6 \mathrm{~h}$ posttreatment (hpt) and $48 \mathrm{hpt}$, while REO induced the highest upregulation at $0.5 \mathrm{hpt}$, which then decreased over time. Furthermore, CS-REO treatment delayed gene upregulation by REO alone, from 0.5 to $6 \mathrm{hpt}$, and kept that longer over time. This study suggests that CS stabilizes the volatile and/or hydrophobic substances of highly reactive essential oils. The additive effects of CS and REO were able to reduce postharvest decay and affect gene expression in papaya fruit.

Keywords: chitosan, essential oils, gene expression, induced resistance, RT-qPCR 


\section{INTRODUCTION}

Papaya (Carica papaya) is a fruit cultivated in tropical and subtropical regions but appreciated worldwide. It is known for its high nutritional and economic potential (Parven et al., 2020). Papaya fruit is rich in vitamins $\mathrm{A}$ and $\mathrm{C}$, and in gallic acid, alkaloids, flavonoids, other phenolic compounds, and papain, an enzyme with extensive uses in the pharmaceutical, medical, and food industries (Brishti et al., 2013; Jarisarapurin et al., 2019). However, being a climacteric fruit, it is subject to intense metabolic activity, fast maturation, high susceptibility to fungal diseases, and short shelf life (Batista et al., 2020).

The most common fungal disease of papaya fruit is anthracnose, which is caused by Colletotrichum spp. and can result in 30-50\% postharvest losses (Gunathilake et al., 2018). Several technologies have been used to extend the postharvest shelf life of fruit, including fungicides, low-temperature storage, thermal processing, diverse packaging conditions, and preserving compounds obtained from natural sources that are "generally recognized as safe" (Droby and Wisniewski, 2018). Exports of papaya fruit have been projected to grow at $1.7 \%$ per year over the medium term by the United Nations Food and Agriculture Organization, to potentially reach 3,18,000 t of fruit by 2028 (Food and Agricultural Organization of the United Nations, 2020). This, thus, indicates the opportunity for significant trade growth.

Chitosan (CS) is a natural biocompatible polysaccharide that is known to be an effective eco-friendly alternative to synthetic fungicides (Mutjaba et al., 2019; Rajestary et al., 2021). In recent years, CS has been used as a natural fungicide and plant defense booster based on its antimicrobial, film-forming, and eliciting defense activities (Feliziani et al., 2015; Romanazzi et al., 2018; Duan et al., 2019). Because of its film-forming properties, it can be used as a coating for many fruits and vegetables, to create a modified atmosphere around the product that prolongs the shelf life and retains the physicochemical and sensory properties (Valencia-Chamorro et al., 2011; Romanazzi et al., 2018). CS can elicit defense mechanisms of papaya (Ali et al., 2012), peach (Ma et al., 2013), banana (Hernández-Ibáñez et al., 2013), strawberry (Landi et al., 2014, 2017), orange (Coqueiro et al., 2015), avocado (Obianom et al., 2019), and grapes (Zhang Z. et al., 2020).

The physicochemical properties of CS relate to its hydrophilic nature, and these can be reinforced with the introduction of hydrophobic compounds, such as some essential oils (EOs). EOs such as those obtained from Cymbopogon citratus, Origanum vulgare, and Thymus capitatus, among others, have shown encouraging benefits when used as postharvest strategies for food preservation (Pisoschi et al., 2018; Sivakumar and Romanazzi, 2019). However, EOs are highly volatile, and thus their persistence on products when applied can be low (AlonsoGato et al., 2021). This inconvenience could be reduced by encapsulating such EOs in polymers such as CS to potentially use them as alternatives to traditional fungicides (Rodríguez et al., 2016). In recent years, the use of CS-based composite coatings that incorporate EOs has been proposed as postharvest treatments for fruit (Yuan et al., 2016; Grande-Tovar et al., 2018). In most cases, these studies have confirmed the conservation of fruit physicochemical properties, inhibition of pathogenic microorganisms, and the extension of shelf life of fruit (Munhuweyi et al., 2017; Lima Oliveira et al., 2018). More recently, it was reported that an emulsion formed from $2 \% \mathrm{CS}$ combined with different concentrations of Ruta graveolens (rue) EO (REO) has efficacy as a coating of postharvest fruit, with extended shelf life seen for guava (Grande Tovar et al., 2019), gooseberry (González-Locarno et al., 2020), tomato (PeraltaRuiz et al., 2020b), pear (Peralta-Ruiz et al., 2021), and papaya (Peralta-Ruiz et al., 2020a). However, to our knowledge, the mechanisms associated with the protective effect induced by REO and CS-REO treatments in fruit are not well understood. It is well known that plant immune regulation is a defensive strategy of plants for protection against pathogen invasion, in addition, some substances can induce plant autoimmunity regulation mechanisms. In this context as mentioned above, CS is well known as an elicitor of plant defense responses, while the defense mechanism induced by REO and CS-REO combination was not investigated. Thus, the objectives of this study were to determine if the treatments of the papaya fruit with $0.5 \% \mathrm{CS}$, $0.5 \%$ REO, and $0.5 \%$ CS-REO combination were able to induce resistance and/or the activation of plant defense mechanisms, testing the early gene expression of key genes involved in plant response against biotic and abiotic stress. Furthermore, the effectiveness of postharvest control of anthracnose following treatments was analyzed.

\section{MATERIALS AND METHODS}

\section{Fruit Samples}

Papaya fruits cultivated in Brazil were obtained from a local market in Ancona (Marche region, Italy) at the third maturation stage according to the maturity scale proposed by Santamaría et al. (2009). Fruits with signs of mechanical damage, incorrect maturity, physical damage, or disease were discarded, and the remaining fruits were standardized according to size, shape, and visual uniformity of color. They were then surface disinfected for $1 \mathrm{~min}$ with sodium hypochlorite solution $\left(200 \mathrm{mg} \mathrm{L}^{-1}\right)$, and rinsed with distilled water (Lima Oliveira et al., 2018).

\section{Preparation of the Emulsion}

A commercial CS-hydrochloride-based formulation (Chitosano; Agrilaete, Italy) was prepared according to the instructions on the product label; the powder product was added to distilled water and dissolved by stirring overnight on a magnetic stirrer. The REO was obtained from Kräuter SAS (Bogotá, Colombia).

To prepare the CS and/or REO emulsions, the methodology reported by Peralta-Ruiz et al. (2020a) was followed, with some modifications. Here, $0.75 \mathrm{ml}$ glycerol per g CS was initially added to $0.5 \%(\mathrm{w} / \mathrm{v}) \mathrm{CS}$ as a plasticizer, followed by thorough agitation of the solution. Triton X-100 (Sigma-Aldrich, Germany) was used as an emulsifier, by incorporation at $1 \%(\mathrm{v} / \mathrm{v})$ vs. REO. Finally, the REO was added directly into the CS hydrochloride dispersion under agitation, to obtain an emulsion with a final concentration of $0.5 \%(\mathrm{v} / \mathrm{v})$ REO. The REO alone emulsion was prepared following the same procedure above but without CS. 


\section{Postharvest Treatments}

Papaya fruits without apparently visual damage were randomly divided into four groups and treated with the emulsions using a concentration of REO of $0.5 \%$. This concentration was used because in previous work we observed that this amount had a sublethal effect on Colletotrichum gloeosporioides (Peralta-Ruiz et al., 2020a). Three replicates of 20 fruits were used for each treatment and the control. The papayas were carefully coated with the emulsion following the relevant treatment $(0.5 \% \mathrm{CS}$, $0.5 \% \mathrm{REO}$, and $0.5 \% \mathrm{CS}-\mathrm{REO}$ ) by their complete immersion for $2 \mathrm{~min}$, to the control samples was used water. The concentrations of CS were selected because, in a preliminary experiment, we observed a significant reduction of $C$. gloeosporioides. The fruits were then air-dried and kept in plastic boxes at $25 \pm 1^{\circ} \mathrm{C}$ and $62 \%$ relative humidity for 9 days.

\section{Decay Evaluation}

To determine the numbers of decayed fruit after the storage period ( 9 days), we used the relative decay measurement (number of decayed fruit/number of total fruit) for each treatment. Decay severity $(D S)$ was also calculated according to the methodology proposed by Romanazzi et al. (2013), following an empirical 0-5 rating scale according to the fruit surface infected: 0 , healthy fruit; $1,1-20 \%$ infected; $2,21-40 \%$ infected; $3,41-60 \%$ infected; $4,61-$ $80 \%$ infected; $5, \geq 81 \%$ infected. McKinney's disease index $(M I)$ was calculated according to Eq. (1) (McKinney, 1923):

$$
M I=\left[\frac{1 n+2 n+3 n+4 n+5 n}{N \times D}\right] \times 100
$$

Where $n$ is the number of fruit classified in each category of DS, $\mathrm{N}$ is the total number of fruit examined (i.e., healthy and infected), and D is the highest category of DS that occurred on the empirical scale used.

The in situ effects of the CS-REO combination were determined using Abbott's equation for synergy calculation, following the method reported by Rahman et al. (2014), with some modifications. First, the protection index $(P I)$ was calculated for the DS for each treatment, according to Eq. (2):

$$
P I=\frac{\left(D S_{\text {control }}-D S_{\text {treatment }}\right)}{D S_{\text {control }}} \times 100
$$

Then, the expected efficacy $\left(E_{\text {exp }}\right)$ was calculated according to Eq. (3):

$$
E_{\text {exp }}=P I_{C S}+P I_{R E O}-\left(\frac{P I_{C S} \times P_{R E O}}{100}\right)
$$

The synergistic effects (Abbott index; $A I$ ) were calculated according to Eq. (4):

$$
A I=\frac{E_{\text {obs }}}{E_{\text {exp }}}
$$

Where $\mathrm{E}_{\mathrm{obs}}$ is the PI determined for the 0.5\% CS-REO treatment. A synergistic effect was assigned for $A I \geq 1.5$, an additive effect for $0.5 \leq A I<1.5$, and an antagonistic effect for $A I<0.5$ (Peralta-Ruiz et al., 2020a).

\section{Gene Expression Analysis}

To assess the ability of treatments to induce defense response on the papaya fruit, the relative gene expression by reverse transcription quantitative real-time PCR (RT-qPCR) method was performed according to Minimum Information for Publication of Quantitative Real-Time PCR Experiments (MIQE) guidelines (Bustin et al., 2009).

\section{Sample Treatment}

The gene expression study for the papaya fruit was performed according to the four different treatments (control-water, 0.5\% CS, $0.5 \%$ REO, and 0.5\% CS-REO), previously described. After the treatments, the fruits were arranged in plastic boxes and stored for $0.5,6,24,48$, and $72 \mathrm{~h}$, at $25^{\circ} \mathrm{C}$ and $95-98 \%$ relative humidity. At each time, three fruits per treatment were peeled to a thickness of $\sim 5 \mathrm{~mm}$ using a potato peeler, thus, removing the epicarp (outer skin) and some of the mesocarp (edible part). The fruit tissue samples for each treatment $(30 \mathrm{~g})$ were frozen in liquid nitrogen and stored in plastic bags at $-80^{\circ} \mathrm{C}$ until RNA extraction. The experiments were repeated at least twice.

\section{RNA Extraction}

High-quality total RNA was obtained from the fruit following the methodology of Landi et al. (2014). Briefly, $30 \mathrm{~g}$ papaya fruit tissue was ground in liquid nitrogen, and $400 \mathrm{mg}$ of the resulting fruit powder was randomly collected for RNA extraction. Extraction buffer was added [1 ml; $100 \mathrm{mM}$ Tris$\mathrm{HCl}, \mathrm{pH}$ 8.0, $25 \mathrm{mM}$ ethylenediaminetetraacetic acid disodium salt (EDTA), $\mathrm{pH} 8.0,2 \%(\mathrm{w} / \mathrm{v})$ hexadecyltrimethylammonium bromide (CTAB) (Sigma), 2\% (v/v) $\beta$-mercaptoethanol, $2.5 \mathrm{M}$ $\mathrm{NaCl}, 2 \%(\mathrm{w} / \mathrm{v})$ soluble polyvinylpyrrolidone-40 (PVP-40)], and the samples were incubated at $65^{\circ} \mathrm{C}$ for $40 \mathrm{~min}$. The supernatants were then transferred to new tubes with an equal volume of chloroform/isoamyl alcohol (24:1) and mixed and centrifuged at $10,000 \times g$ for $8 \mathrm{~min}$ at $4^{\circ} \mathrm{C}$. This last step was repeated two more times. The total RNA was precipitated in 0.25 vol. $10 \mathrm{M} \mathrm{LiCl}$, and kept overnight at $4^{\circ} \mathrm{C}$. The samples were then centrifuged at $10,000 \times g$ for $30 \mathrm{~min}$ at $4^{\circ} \mathrm{C}$, washed in $70 \%$ ethanol, dried, and resuspended in $50 \mu \mathrm{l}$ double-distilled diethyl pyrocarbonate water. The RNA quality was determined based on an absorbance ratio of 1.80 to 2.00 at $260 / 280 \mathrm{~nm}$, and 1.5 to 2.0 at 260/230 nm, using a spectrometer (BioPhotometer plus; Eppendorf Inc., Westbury, NY, United States).

\section{Reverse Transcription}

First-strand cDNA was synthesized using iScript TM cDNA synthesis kits (Bio-Rad Laboratories, Hercules, CA, United States) from $40 \mathrm{ng}$ RNA, according to the instructions of the manufacturer. From the RNA of each biological replicate, the cDNA synthesis was performed twice, with the products $(20 \mu \mathrm{l}$ each) mixed and diluted (1/10) according to preliminary tests, with an aim to have an adequate quantity of cDNA to analyze all the selected genes. 


\section{Primer and Reference Gene Selection}

Primers were designed using Primer3 software $7^{1}$, according to 17 key target genes that code for enzymes linked to signaling pathways that regulate plant defense, pathogenesisrelated $(\mathrm{PR})$ protein, cell wall-degrading enzymes, control of redox, abiotic stress, and secondary metabolism of the phenylpropanoid pathway. To screen the most stable reference genes, four housekeeping genes, $18 S$ ribosomal RNA (18SRNA), $\alpha$-tubulin (tub), elongation factor 1 (tuf), and histone H1 (H1), were selected. The genes were identified from the specific sequence of $C$. papaya deposited in National Center for Biotechnology Information (NCBI) GenBank. The main functions of the genes and the related coding enzymes analyzed in this study are reported in Table 1. The primer pairs were chosen and validated in silico using primer BLAST specific analysis ${ }^{2}$, and then according to the melting profiles obtained by RT-qPCR, as described later. The stabilities of candidate reference genes were evaluated using algorithms: geNorm module of qbase + (Biogazelle) (Vandesompele et al., 2002). These algorithms rank the reference genes based on the stability value ( $M$-value). A lower $M$-value corresponds to a more stable gene. The recommended stability for homogenous samples is $M$-value $<0.5$ [coefficient of variation, $(\mathrm{CV})<0.25$ ]; and for heterogeneous samples is $M$-value $<1(\mathrm{CV}<0.5)$ (Bustin et al., 2009).

\section{Quantitative Real-Time PCR}

The RT-qPCR reactions were carried out in triplicate in a total volume of $12 \mu \mathrm{l}$ each, which contained $5.6 \mu \mathrm{l}$ diluted cDNA, $0.20 \mu \mathrm{M}$ of each primer, and $6 \mu \mathrm{l}$ SsoAdvanced Universal SYBR Green Supermix, using a real-time detection system (CFX Connect; Bio-Rad Laboratories). The cycling conditions were as follows: 4 min denaturation at $95^{\circ} \mathrm{C}$, followed by 40 cycles at $95^{\circ} \mathrm{C}$ for $20 \mathrm{~s}$, and $60^{\circ} \mathrm{C}$ for $40 \mathrm{~s}$. Melting curve analysis was performed over the range of $65-98^{\circ} \mathrm{C}$. All of the assays included no-RT and no-template controls to determine the nonspecific amplification. The RT-qPCR efficiency $(E)$ of each primer pair was determined using standard curves generated according to $E=10-1 /$ slope. The diluted cDNAs from samples (10 $\mu \mathrm{l}$ each) were mixed, and then four serial dilutions 1:5, (initial dilution, 0.2, 0.04, 0.008) were obtained. For each primer pair, the standard curve was generated from two technical replicates.

\section{Statistical Analysis}

For disease incidence, each experiment was repeated at least twice, using a completely randomized block design. The normality of the data was tested using Shapiro-Wilk tests, and the homogeneity of the variances was tested using Levene's test, using STATISTICA ver. 13.0 (TIBCO Inc., Palo Alto, CA, United States). Appropriate transformations were determined using the Skewness coefficient. The arcsine of the square root of the proportion was applied to the disease incidence data.

Relative changes in gene expression data were determined using the $2^{-\Delta \Delta C t}$ method (Livak and Schmittgen, 2001),

\footnotetext{
${ }^{1}$ https://bio.tools/primer3

${ }^{2}$ http://www.ncbi.nlm.nih.gov/Blast.cgi
}

normalized using the reference genes selected in this study, and compared to the untreated control at $0.5 \mathrm{hpt}$. Each gene was analyzed with three technical replicates for each of the two biological replicates $(n=6)$. To evaluate both the effects of the coatings on the papaya fruit and the gene expression variations in response to the treatments, the data from each sampling point were shown as means \pm SD and were statistically evaluated using ANOVA, followed by individual comparisons using Duncan's multiple range tests, with significance set at $p \leq 0.05$. For each treatment at each time point, the relative fold-changes were calculated to relevant controls and shown in the heatmap ${ }^{3}$.

\section{RESULTS}

\section{Fruit Decay}

The effects of the treatments with emulsions of $0.5 \%$ CS, $0.5 \%$ REO, and their combination, CS-REO, on the incidence and severity of the papaya fruit decay over 9 days of storage at $25^{\circ} \mathrm{C}$ are reported in Table 2 and illustrated in Figure 1. The incidence of decay with $0.5 \%$ CS was not statistically different from that of the control fruit. In contrast, for both REO and CSREO treatments, the decay incidence compared to the control was reduced by 21 and 37\%, respectively. The severity of the postharvest decay was reduced compared to the control for all of the treatments; for CS by $22 \%$, for REO by $29 \%$, and CSREO by $44 \%$. The greatest reduction in the McKinney's index was seen for the combined treatment (CS-REO; 50\%). The AI for this combined treatment showed an additive effect between these $0.5 \%$ CS and $0.5 \%$ REO emulsions when applied together to the papaya fruits.

\section{Gene Expression Analysis}

For this study, RT-qPCR was set up to analyze the papaya fruits treated with $0.5 \%$ CS, $0.5 \%$ REO, separately and combined. The melt peak analysis demonstrated a single homogenous peak for all of the primer sets (data not shown), which confirmed the specificity of the amplicons produced in the RTqPCR for each of the 21 target and reference genes examined (Table 3). No amplification was seen in any of the control (water treatment) assays, which confirmed that the samples were free of contamination with genomic DNA or RNA, or the cDNA template (data not shown). Standard curves using a mix of cDNA samples from the papaya fruit were constructed using four points of five-fold serial dilutions of cDNA, which yielded efficiencies that ranged from 90 to $110 \%$ (Bustin et al., 2009; Table 3).

The four putative candidate reference genes $18 S-R N A$, tub, tuf, and $H 1$ were validated according to the geNorm method, and they showed different stability values. The lowest $M$-values, which correspond to the most stable genes, across all of the treatments tested in this study were seen for the tub $(0.3357 \pm 0.046 ; \mathrm{CV}, 0.1352 \pm 0.098)$ and $H 1(0.3775 \pm 0.073$; $\mathrm{CV}, 0.1881 \pm 0.078)$. This indicated that these two reference genes were suitable for the RT-qPCR investigation into these treated papaya fruits. In contrast, $18 S-R N A$ and tuf showed greater

\footnotetext{
${ }^{3}$ http://www.heatmapper.ca/expression/
} 
TABLE 1 | Genes selected for gene expression.

\begin{tabular}{|c|c|c|c|}
\hline Gene name & Abbreviated & NCBI code & Function \\
\hline Salicylic acid binding protein 2 & SABP2 & XM_022039404.1 & $\begin{array}{l}\text { Required to convert methyl salicylate to salicylic acid; part of signal transduction } \\
\text { pathways that activate systemic acquired resistance in systemic tissue (Park et al., } \\
\text { 2009) }\end{array}$ \\
\hline $\begin{array}{l}\text { Suppressor of npr } 1-1 \text {, } \\
\text { constitutive } 1\end{array}$ & SNC1 & XM_022056966.1 & $\begin{array}{l}\text { Disease resistance protein involved in salicylic acid dependent defense response } \\
\text { pathway. Triggers a defense system that promotes programmed cell death (Zhu et al., } \\
\text { 2010) }\end{array}$ \\
\hline Pathogenesis related protein 1 & $P R-1$ & XM_022048043.1 & $\begin{array}{l}\text { Involved in defense reactions of plants against pathogens. Long been used as marker } \\
\text { for salicylic-acid-mediated disease resistance (Gao et al., 2015) }\end{array}$ \\
\hline $\begin{array}{l}\text { Jasmonate } \\
\text { O-methyltransferase }\end{array}$ & $J M T$ & XM_022037106.1 & $\begin{array}{l}\text { Catalyzes methylation of jasmonate into methyl jasmonate. Acts as cellular regulator in } \\
\text { different processes and defense responses (Seo et al., 2001) }\end{array}$ \\
\hline $\begin{array}{l}\text { Linoleate } 13 S \text {-lipoxygenase } \\
2-1, \text { chloroplastic }\end{array}$ & LOX2 & XM_022052808.1 & $\begin{array}{l}\text { Involved in diverse aspects of plant physiology, including pest resistance and } \\
\text { senescence. Involved in bulk production of jasmonate upon wounding (Bannenberg } \\
\text { et al., 2009) }\end{array}$ \\
\hline $\begin{array}{l}\text { Ethylene receptor, transcript } \\
\text { variant } X 2\end{array}$ & ETR2 & XM_022038539.1 & $\begin{array}{l}\text { Related to bacterial two-component regulators. Acts as negative regulator of ethylene } \\
\text { signaling (O'Malley et al., 2005) }\end{array}$ \\
\hline $\begin{array}{l}\text { Ethylene responsive } \\
\text { transcription factor } R A P 2-13\end{array}$ & RAP2-13 & XM_022041977.1 & $\begin{array}{l}\text { Probably acts as transcriptional activator. Binds to pathogenesis related promoter } \\
\text { element. Maybe involved in regulation of gene expression by stress factors (Paul et al., } \\
\text { 2016) }\end{array}$ \\
\hline Peroxidase 10 & PRX10 & XM_022052459.1 & $\begin{array}{l}\text { Removal of } \mathrm{H}_{2} \mathrm{O}_{2} \text {, oxidation of toxic reductants, biosynthesis and degradation of lignin, } \\
\text { auxin catabolism, response to oxidative stresses, wounding, and pathogen attack } \\
\text { (Rhee et al., 2001) }\end{array}$ \\
\hline Pathogenesis related protein 5 & $P R-5$ & XM_022040713.1 & Involved in response to pathogens (El-Kereamy et al., 2011) \\
\hline Chitinase 2 & Cht2 & XM_022055626.1 & Encodes chitinase-like protein expressed predominantly in stems (Hossain et al., 2010) \\
\hline $\begin{array}{l}\text { Endo-1,3;1,4-beta-D- } \\
\text { glucanase }\end{array}$ & GLUC & XM_022049329.1 & $\begin{array}{l}\text { Role in control of plant growth. Mediates specific degradation of cell wall (Thomas et al., } \\
\text { 2000) }\end{array}$ \\
\hline Polygalacturonase & $P G$ & XM_022056889.1 & $\begin{array}{l}\text { Important pectolytic glucanase, primarily implicated in softening of fruit during ripening } \\
\text { (García et al., 2009) }\end{array}$ \\
\hline NAC domain protein & $N A C$ & XM_022052621.1 & $\begin{array}{l}\text { Transcription factors highly responsive to abiotic stresses. NACs have roles in } \\
\text { maintaining water status under drought or salt conditions (Lv et al., 2016) }\end{array}$ \\
\hline $\begin{array}{l}\text { Heat shock cognate } 70 \mathrm{kDa} \\
\text { protein } 2\end{array}$ & HSP70 & XM_022054737.1 & $\begin{array}{l}\text { In cooperation with other chaperones, key components that facilitate folding of de novo } \\
\text { synthesized proteins; also responsible for degradation of damaged proteins under } \\
\text { stress (Ahn et al., 2005) }\end{array}$ \\
\hline $\begin{array}{l}\text { Anthocyanidin } \\
\text { 3-O-glucosyltransferase }\end{array}$ & UFGT & XM_022051791.1 & $\begin{array}{l}\text { Participates in flavonoid biosynthesis; involved on defense against pathogen attack (Hu } \\
\text { et al., 2011) }\end{array}$ \\
\hline Flavonol synthase & FLS & XM_022056718.1 & $\begin{array}{l}\text { Participates in flavonoid biosynthesis; involved in defense against pathogen attack } \\
\text { (Hammerbacher et al., 2019) }\end{array}$ \\
\hline Phenylalanine ammonia-lyase & $P A L$ & XM_022032339.1 & $\begin{array}{l}\text { Key enzyme in phenol synthesis pathway; considered primary inducible response in } \\
\text { plants against several biotic and abiotic stresses (Kim and Hwang, 2014) }\end{array}$ \\
\hline Elongation factor 1 & Tuf & XM_022042067.1 & $\begin{array}{l}\text { Responsible for enzymatic delivery of aminoacyl tRNAs to ribosomes, (Sasikumar et al., } \\
\text { 2012) }\end{array}$ \\
\hline$\alpha$-tubulin & Tub & XM_022035406.1 & $\begin{array}{l}\text { Polymerizes into long chains or filaments that form microtubules; hollow fibers that } \\
\text { serve as skeletal system for living cells (Janke and Magiera, 2020) }\end{array}$ \\
\hline Histone H1 & $H 1$ & XM_022052470.1 & $\begin{array}{l}\text { Dominant role in establishing compaction state of nucleosomes and influencing } \\
\text { conformation (Woodcock et al., 2006) }\end{array}$ \\
\hline $18 S$ ribosomal RNA & 18S-RNA & U42514.1 & Active center of protein synthesis in 40 S ribosomal subunit (Poltronieri and Hong, 2015) \\
\hline
\end{tabular}

The main functions of the gene products are also given. Bold, reference genes.

TABLE 2 | Effects of the chitosan (CS), Ruta graveolens essential oil (REO), and CS-REO treatments on the incidence and severity of the papaya fruit decay after 9 days of storage at $25 \pm 1^{\circ} \mathrm{C}$.

\begin{tabular}{|c|c|c|c|c|c|}
\hline Treatment & Disease incidence (\%) & Disease severity (1-5) & McKinney's index (\%) & Protection Index (\%) & Abbott Index \\
\hline Control (water) & $95.0 \pm 10.0 \mathrm{a}$ & $4.5 \pm 0.38 \mathrm{a}$ & $90 \pm 7.7 \mathrm{a}$ & - & - \\
\hline $0.5 \%$ CS & $84.5 \pm 11.9 \mathrm{ab}$ & $3.5 \pm 0.11 b$ & $70 \pm 2.3 b$ & $21.8 \pm 5.6 b$ & - \\
\hline $0.5 \%$ REO & $75.4 \pm 11.1 \mathrm{~b}$ & $3.2 \pm 0.25 b$ & $63 \pm 5.0 b$ & $29.4 \pm 8.6 b$ & - \\
\hline $0.5 \%$ CS+REO & $60.0 \pm 0.0 \mathrm{c}$ & $2.5 \pm 0.11 c$ & $50 \pm 2.3 c$ & $44.3 \pm 2.5 \mathrm{a}$ & 1.0 \\
\hline
\end{tabular}

Data are means $\pm S D$.

Different letters within columns indicate significant differences between treatments ( $p \leq 0.05$; Duncan's multiple range tests). 
$\mathbf{A}$

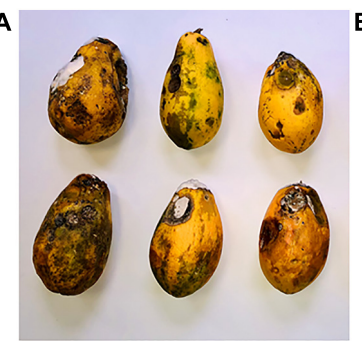

C

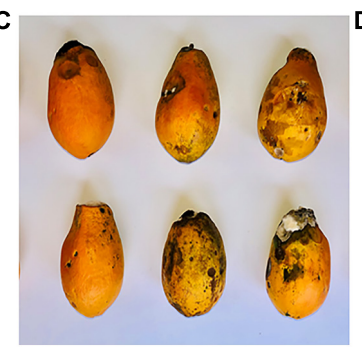

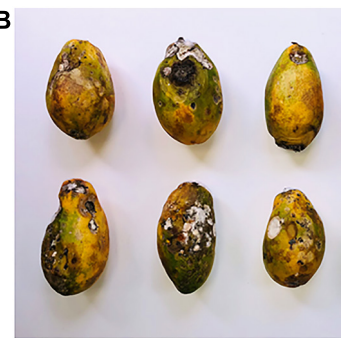

D

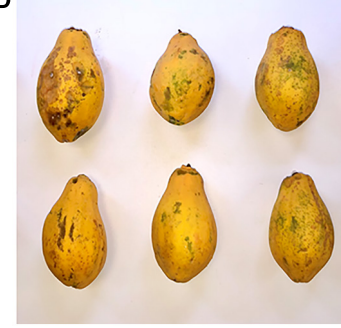

FIGURE 1 | Representative images of incidence of postharvest decay in papaya fruit following 9 days of storage at $25^{\circ} \mathrm{C} \pm 1^{\circ} \mathrm{C}$ after the treatments with water (A; control), 0.5\% chitosan (CS) (B), 0.5\% Ruta graveolens essential oil (REO) (C), and their combination $0.5 \%$ chitosan, $0.5 \%$ Ruta graveolens essential oil (CS-REO) (D).

instabilities according to the $M$-values $(0.7264 \pm 0.124 ; \mathrm{CV}$, $0.4012 \pm 0.072 ; 0.6354 \pm 0.12 ; C V, 0.5147 \pm 0.101$; respectively)

The gene expression data were discussed according to their relative fold-changes compared to relevant controls.

\section{Genes Involved in Signaling Pathways That Regulate Plant Defense}

$S A B P 2$ is involved in the salicylic acid (SA) pathway. Its levels of expression in the fruit treated with CS showed moderate upregulation at $6 \mathrm{hpt}$ and $24 \mathrm{hpt}$, of $\sim 2$-fold, compared to the relevant control. However, its greatest upregulation was at $48 \mathrm{hpt}$, at 9.9-fold. After REO treatment, SABP2 expression increased more rapidly, to initially peak at 0.5 hpt at 19.9 -fold, and then increased again to 6.3-fold at $24 \mathrm{hpt}$. Then for CSREO, SABP2 showed increased expression at 6, 24, and $48 \mathrm{hpt}$ of 9.2-fold, 5.9-fold, and 8.7-fold, respectively, with respect to the control (Figures 2, 3). Expression of the SNC1 gene suppressor of NPR1 was correlated with $S A B P 2$ expression. Indeed, after CS treatment, SNC1 expression increased at $48 \mathrm{hpt}$ to 4.5 -fold, while after REO treatment, it was upregulated at $0.5 \mathrm{hpt}$ by 14.9 fold and at 24 hpt by 3.8 -fold. Finally, after CS-REO treatment, SNC1 showed increased expression at 6,24, and $48 \mathrm{hpt}$, of approximately 5-fold to 7.5-fold (Figures 2, 3). The JMT gene is a part of the jasmonate pathway, and its expression levels in the papaya fruits were not affected by CS treatment, while REO increased JMT expression at 0.5 hpt by 9.4 -fold, and at 24 hpt by 2.9-fold. JMT was upregulated with the CS-REO treatment at 24 and $48 \mathrm{hpt}$, by 5.6-fold for both (Figures 2, 3). Like for JMT, the LOX2 gene participates in jasmonate synthesis, and its expression was also not affected by CS. Instead, after REO treatment, this transcript was upregulated at $0.5 \mathrm{hpt}$ by 5.5 -fold, followed by downregulation at $6 \mathrm{hpt}$ of -2.8 -fold. The CS-REO treatment

upregulated JMT at 6 and $24 \mathrm{hpt}$, by 1.7 -fold and 4-fold, respectively (Figures 2, 3). For the genes involved in ethylene (ET) transcription, the expression of both ETR-2 and RAP213 was upregulated after CS treatment mainly at 6 and $48 \mathrm{hpt}$ : for ET-2, by 5.2-fold and 4.5-fold, respectively, and for RAP213, by 2.6-fold and 3.6-fold, respectively (Figures 2, 3). After REO treatment, ETR-2 and RAP2-13 showed similar expression profiles, with strong upregulation at $0.5 \mathrm{hpt}$, of 10.7 -fold and 12.6fold, respectively (Figures 2, 3). Then, ETR-2 was upregulated at 6 and $24 \mathrm{hpt}$ by 2 -fold and at $72 \mathrm{hpt}$ by 6 -fold, while at $24 \mathrm{hpt}, \mathrm{RAP2}-13$ was upregulated by 2.7-fold (Figures 2, 3). For CS-REO treatment, there was upregulation of ETR-2 at 0.5, 6 , and $48 \mathrm{hpt}$ of 12-fold, 16-fold, and 8.8-fold, respectively, while RAP2-13 expression was upregulated at 0.5 hpt by $2.4-$ fold, at 6 hpt by 12.6-fold, and at 24 and 72 hpt by about 3 -fold (Figures 2, 3).

\section{Genes Involved in Oxidative Stress}

The CS treatment upregulated PRX10 expression at $48 \mathrm{hpt}$ by 19.4-fold, while REO treatment showed upregulation at 0.5, 24, and $48 \mathrm{hpt}$ by 5.6-fold, 2.4-fold, and 2.6-fold. The CS-REO combination promoted a moderate increase in $P R X 10$ expression at $0.5 \mathrm{hpt}$, of 1.8 -fold, while greater upregulation was seen at $6 \mathrm{hpt}$ and $48 \mathrm{hpt}$, of 6.8-fold and 18.6-fold, respectively (Figures 2, 3).

\section{Genes for PR Proteins}

For the PR-1 gene, its expression increased after both CS and CSREO treatments, mainly at $0.5,6$, and $24 \mathrm{hpt}$, at 6.1-fold, 8.1-fold, 3.4-fold, and 4.6-fold, 9.1-fold, and 3.2-fold, respectively. The PR1 gene up-regulation was observed also at $72 \mathrm{hpt}$ by 2.4 -fold by CS-REO. After the REO treatments, $P R-1$ expression increased mainly at 6 hpt, by 9 -fold, and at 72 hpt, by 2.4-fold (Figures 2, 3). The PR-5 gene was upregulated only after REO treatment, and at $0.5,24$, and $48 \mathrm{hpt}$, by 2.9 -fold, 2.1 -fold, and 4.1 -fold. The downregulation was observed at $48 \mathrm{hpt}$ by 3.5 -fold by CS, were no changes in $P R-5$ gene expression with CS-REO treatments (Figures 2, 3).

\section{Genes for Cell Wall-Degrading Enzymes}

The expression of Cht 2 was upregulated after CS treatment at 6 and $48 \mathrm{hpt}$, by 2.8 -fold and 5-fold, respectively; conversely, after REO treatment, the gene was upregulated at 0.5 and $6 \mathrm{hpt}$, by 20.7 -fold and 5.8 -fold, respectively. The CS-REO treatment combination increased Cht 2 expression at 6, 24, and $72 \mathrm{hpt}$, by 12.8-fold, 7.21-fold, and 2.5-fold (Figures 3, 4).

Similar to Cht2, after CS treatment, GLUC expression increased at 6 and $48 \mathrm{hpt}, 2.4$-fold, and 3.5-fold, respectively. The REO treatment upregulated GLUC at $0.5,6$, and $48 \mathrm{hpt}$ by 4.6 -fold, 3.3-fold, and 1.8-fold, respectively, while CS-REO upregulated GLUC mainly at $6 \mathrm{hpt}$, by 10 -fold (Figures 3, 4).

The $P G$ gene was upregulated after all of the treatments at all of the time points by $>3.8$-fold, except for REO at $0.5 \mathrm{hpt}$. However, the greatest $P G$ expression after CS was at $0.5 \mathrm{hpt}$, at 7.7-fold, while for both REO and CS-REO treatments, high $P R$ expression was also seen at $6 \mathrm{hpt}$, at 16.9-fold, and 19.5-fold, respectively (Figures 3, 4). 
TABLE 3 | Primer pairs were selected for gene expression analysis and related PCR amplification efficiencies data.

\begin{tabular}{|c|c|c|c|c|c|}
\hline Gene code & Primers ( $5^{\prime}$ forward $/ 5^{\prime}$ reverse) & Amplicon size (bp) & Melt curve peak $\left({ }^{\circ} \mathrm{C}\right)$ & PCR efficiency (\%) & $\begin{array}{c}R^{2} \text { for standard } \\
\text { curve }\end{array}$ \\
\hline SABP2 & 5'gataggcccggttggtattt/5'aagggcatcatgagatttgg & 172 & 80.0 & 101.8 & 0.997 \\
\hline SNC1 & $5^{\prime}$ ctgattccgtgcttgttgaa/5'taccccaaattcccaccata & 171 & 79.5 & 106.7 & 0.983 \\
\hline$P R-1$ & $5^{\prime}$ tctcacttgggacaccactg/5'atgcccacaaacttttccag & 220 & 88.5 & 99.6 & 0.997 \\
\hline$J M T$ & $5^{\prime}$ attgcagacctgggttgttc/5'ggaacctgcaattccagaaa & 234 & 82.5 & 107.2 & 0.998 \\
\hline LOX2 & $5^{\prime}$ ctccgtgcatgctgtttcta/5'tcaacgctaacaagctccaa & 207 & 84.5 & 98.9 & 0.998 \\
\hline ETR2 & $5^{\prime}$ cgcttgaaagaggaagcact/5'aaactgcacaaggacccatc & 211 & 82.0 & 97.1 & 0.984 \\
\hline$R A P 2-13$ & 5'ccaagaaccgtacccgtcta/5'cagacctttgcttcccagag & 249 & 87.0 & 107.1 & 1.000 \\
\hline$P R \times 10$ & 5'cagcaaacaaagatggagca/5'gatcgggacacgttttctgt & 249 & 85.0 & 102.1 & 0.998 \\
\hline PR-5 & 5'ctcagagcacggagaaggac/5'tactcggccgtgttaaaagc & 214 & 89.0 & 107.7 & 1.000 \\
\hline Cht2 & 5'gatcctgacagtggcaatca/5'ccacaggcgtgttacgttta & 227 & 81.0 & 107.8 & 0.991 \\
\hline GLUC & 5'tctctcatttccctcgcatt/5'cgacgacgtaggtgtcaaga & 261 & 83.5 & 108.7 & 0.998 \\
\hline$P G$ & 5'tggtggtgcgtatagatgga/5'tgttccgggagttgagaaac & 213 & 85.5 & 98.54 & 1.000 \\
\hline NAC & 5'ggatcgggtatgaagagcaa/5'atttggggctcttcctttgt & 280 & 84.5 & 106.1 & 0.997 \\
\hline HSP70 & 5'gagaagtgcttgagggatgc/5'gtacagcagcaccataggc & 176 & 84.0 & 102.8 & 0.997 \\
\hline UFGT & 5'gatgaatcgcagctgaaaca/5'agatcgaattccacccacag & 244 & 88.0 & 97.6 & 0.995 \\
\hline FLS & 5'tgatagccgatgagctgttg/5'acaccgagaaccaaatcagg & 189 & 81.5 & 103.6 & 0.998 \\
\hline$P A L$ & 5'tgttgcagggctattcagga/5'ccaccatcgattccagcaag & 238 & 82.0 & 101.3 & 0.997 \\
\hline tuf & 5'ctggaaagtcgaccaccact/5'aggggcatcaataacagtgc & 227 & 84.0 & 102.0 & 0.996 \\
\hline tub & 5'gagcacactgatgtggcagt/5'ggaacaaggttggtctggaa & 197 & 80.5 & 104.5 & 0.987 \\
\hline$H 1$ & 5'acatggaagggaagcacaag/5'cgacttcttcgaggtcttgg & 179 & 83.5 & 102.7 & 0.986 \\
\hline 18S-RNA & 5'agaaacggctaccacatcca/5'acccaaggtccaactacgag & 247 & 83.5 & 102.8 & 0.997 \\
\hline
\end{tabular}

PCR amplicon size, amplification efficiencies, and regression coefficients for the standard curves are reported for each primer pair. Bold, reference genes.

\section{Genes Involved in Abiotic Stress}

After CS treatment, the NAC gene was downregulated at 6, 24, and $72 \mathrm{hpt}$, at -1.6 -fold, -1.7 -fold, and -7.7 -fold, respectively (Figures 3, 4). Instead, REO treatment strongly increased NAC expression at $0.5 \mathrm{hpt}$ at 26.8 -fold, followed by downregulation at 6 and 72 hpt at -6.25 -fold and -4 -fold (Figures 3,4 ). In contrast, CS-REO affected NAC expression only at $48 \mathrm{hpt}$, when it was upregulated by 3.4-fold (Figures 3, 4).

The HSP70 expression after CS treatment was upregulated at 6,48 , and 72 hpt by 5.2 -fold, 3.3 -fold, and 2.4 -fold, respectively, while, after REO treatment, this occurred at 0.5 and $72 \mathrm{hpt}$, by 24.2 -fold and 7.9-fold, respectively. With CS-REO treatment, HSP70 was upregulated at 6,48 , and $72 \mathrm{hpt}$ by 2.5 -fold to 3.3 -fold (Figures 3, 4).

\section{Genes Involved in the Phenylpropanoid Pathway}

The PAL, FLS, and UFGT genes are all linked to the phenylpropanoid pathway, and they showed similar gene expression patterns.

In more detail, CS treatment increased PAL expression at 6 and 48 hpt by 2.1 -fold and 13.7-fold, while REO treatment upregulated $P A L$ at 0.5 and 24 hpt by 11.4 -fold and 6.9-fold. Then after treatment with the CS-REO combination, this increased $P A L$ at $6,24,48$, and 72 hpt by 8.7 -fold, 8.3 -fold, 10.7 -fold, and 3.5 -fold, respectively.

The FLS gene was upregulated by CS at 6 and $48 \mathrm{hpt}$, at 3.3-fold and 6.4-fold, by REO at 0.5 and $24 \mathrm{hpt}$, at 3.7-fold and 5.8 -fold, and by CS-REO at 6,24 , and $48 \mathrm{hpt}$, at 6.5 -fold, 5.0-fold, and 6.2-fold.
Finally, the UFGT gene was upregulated by CS at 6,24 , and $48 \mathrm{hpt}$ by 4.4 -fold, 1.9 -fold, and 6.3 -fold, and by REO at 0.5 and $24 \mathrm{hpt}$ by 9.8 -fold and 5.6-fold. The CS-REO treatment upregulated UFGT at 6,24, and $72 \mathrm{hpt}$ by 9.0 -fold, 3.4-fold, and 2.4-fold (Figures 3, 4).

\section{DISCUSSION}

In this study, we evaluated the effectiveness against postharvest anthracnose in papaya fruit of commercial formulations of CS and REO, both individually and combined. Furthermore, we also investigated the effects of these treatments on the activation of the transcription of key genes involved in plant defense mechanisms. In these fruits under postharvest storage at room temperature, and compared to the CS and REO treatments, the CS-REO combination indeed showed the greatest control of fungal decay and severity, as also for the McKinney's Index. Similar results were observed in previous studies on papaya artificially inoculated with C. gloeosporioides, where the fruit treated with CS- $0.5 \%$ REO showed an incidence decay of $60 \%$ and a lower severity lesion (Peralta-Ruiz et al., 2020a). According to the AI, CS-REO showed an additive effect from CS and REO alone, as also indicated by PeraltaRuiz et al. (2020a). Our findings agree with several previous studies that have reported on synergistic or additive effects of CS and EOs in combination for fruit preservation (Yuan et al., 2016; Lima Oliveira et al., 2018; de Oliveira et al., 2020; Elshamy et al., 2021). 

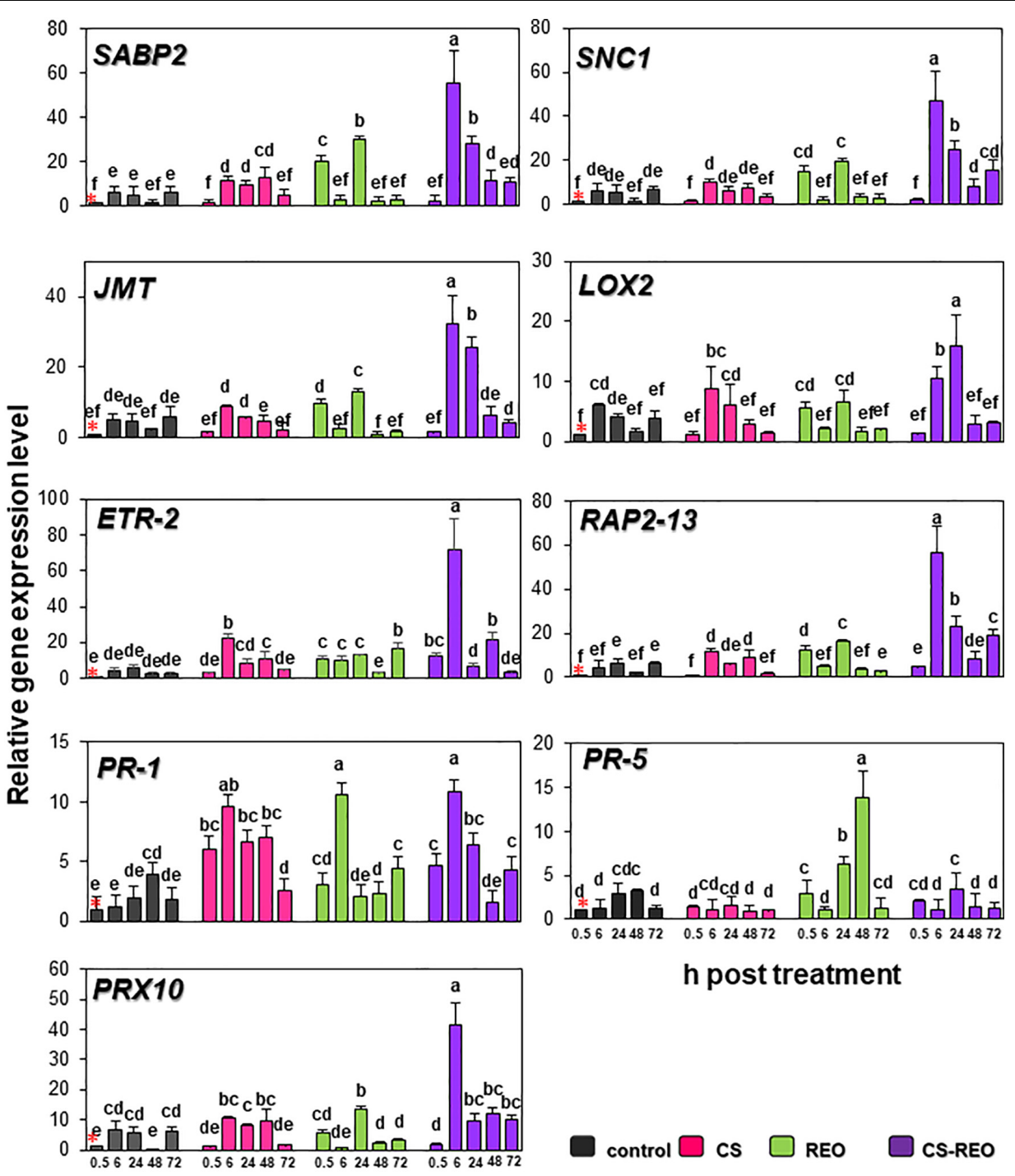

$\mathrm{h}$ post treatment

$\mathrm{h}$ post treatment

FIGURE 2 | Quantification of relative gene expression of nine of the defense genes examined (as indicated; see also Table 1) in papaya fruit following treatments with water (control), $0.5 \%$ CS, $0.5 \%$ REO, and their combination (CS-REO). Each experimental replicate represents three technical replicates $(n=6)$. Gene expression given was relative to control at $0.5 \mathrm{~h}$ posttreatment, also indicated with a red asterisk, according to the $2^{-\Delta \Delta \mathrm{Ct}}$ method (Livak and Schmittgen, 2001$)$. Data are the means $\pm \mathrm{SD}$. Columns with different letters are significantly different $(P \leq 0.05$; Duncan's multiple range tests).

The antifungal properties of CS are usually related to the interactions of its positive amino groups with the fungal membrane, which can induce changes to the permeability of the plasma membrane (Grande-Tovar et al., 2018). Also, the barrier effect of CS inhibits the germination of fungal spores and reduces the fungal decay on fruit (Romanazzi et al., 2018; Rajestary et al., 2021). This can preserve the physicochemical properties of the fruit for longer, thus also prolonging the shelf life (Nair et al., 2020).

In the present study, the effects of CS were reinforced by the addition of REO, which has been observed for other EOs (Sivakumar and Bautista-Baños, 2014; Huang et al., 2021), through their antimicrobial, antifungal, and antioxidant activities
(Grande Tovar et al., 2019; González-Locarno et al., 2020; Peralta-Ruiz et al., 2020a; Zhang D. et al., 2020). It has been reported that the mode of action of such EOs is based on the cytotoxic effects including the induction of cell death by activation of apoptosis and/or necrosis processes (Nazzaro et al., 2017; Sharifi-Rad et al., 2017). Indeed, recent studies have reported that the fungal membrane of C. gloeosporioides was compromised after $1 \mathrm{~h}$ with $1 \%$ REO (Peralta-Ruiz et al., 2020a) and that under similar treatment, Candida yeast showed irreversible cell membrane damage with increased intracellular leakage of macromolecules (Donadu et al., 2021). In addition to the antimicrobial actions, several studies have shown activities as resistance inducers and/or activators of plant defense 


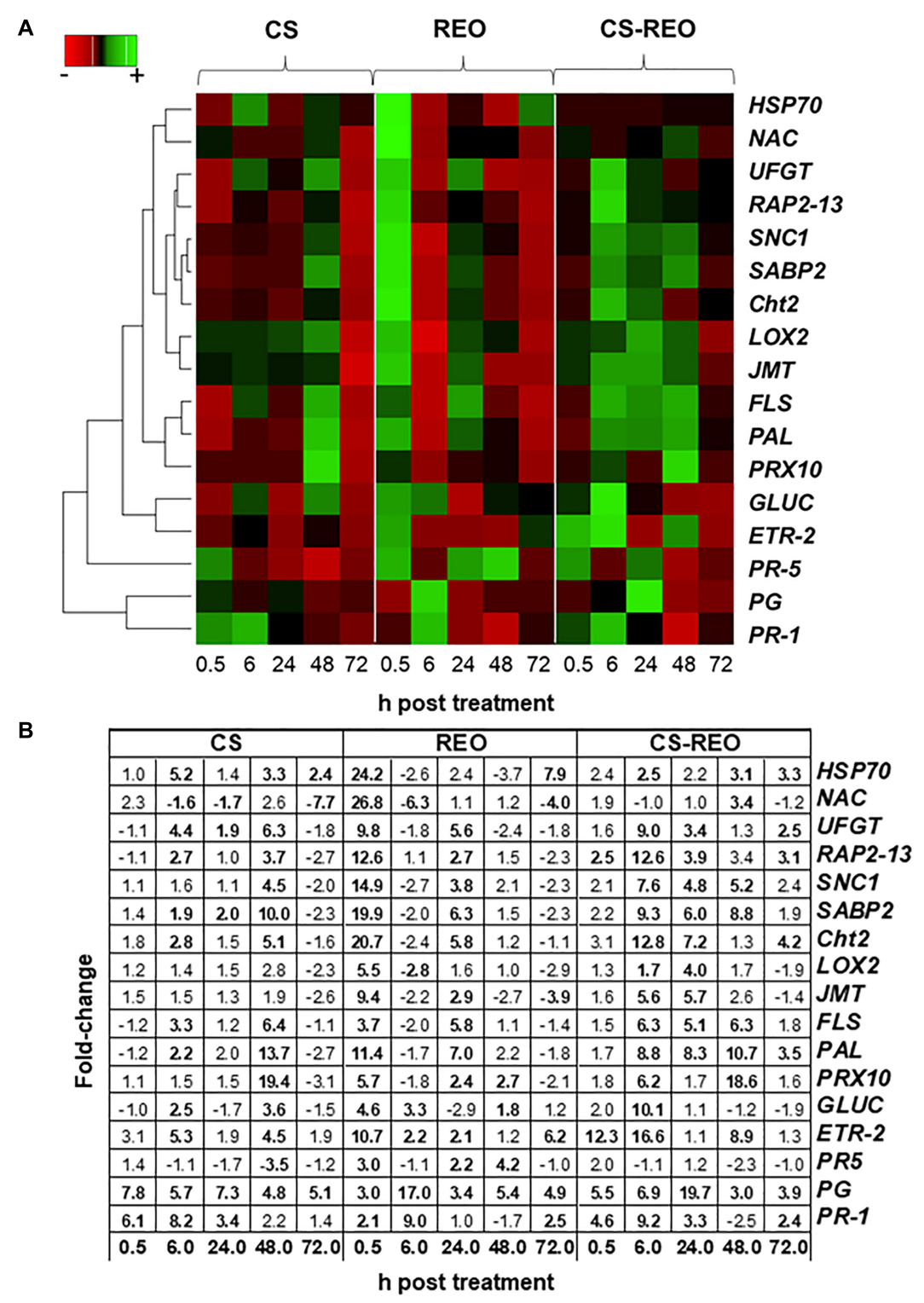

FIGURE 3 | Gene expression heatmap. Hierarchical clustering according to Pearson's correlation similarities and average linkage of the defense genes examined (as indicated; refer to Table 1) in papaya fruit following treatments with 0.5\% CS, 0.5\% REO, and their combination (CS-REO). For each gene, the maximum (green color) and minimum (red color) fold-changes are compared to the control (water) treatment at 0.5, 6, 24, 48, and 72 h posttreatment (A). The average fold-change values compared to the control (water) treatment at 0.5, 6, 24, 48, and $72 \mathrm{~h}$ posttreatment, used for hierarchical clustering, were shown. In bold, the data significantly different $(P \leq 0.05$; Duncan's multiple range tests), compared to relevant controls were indicated (B).

mechanisms for both CS (Ali et al., 2012; Landi et al., 2014, 2017; Coqueiro et al., 2015; Obianom et al., 2019) and EOs (Banani et al., 2018; Hou et al., 2020).

In the present study, we investigated for the first time, the expression of a range of plant defense genes induced by CS and $\mathrm{REO}$ and their combination in the papaya fruit. We selected genes that are involved in key metabolic pathways of plant defense responses to provide basic information on the main mechanisms involved in these actions of such CS-EOs combinations.

We first validated a useful protocol for this gene expression study in papaya fruit using RT-qPCR. This technique has been widely used to evaluate gene expression because of its speed and sensitivity. However, reliable quantification of gene expression mainly depends on accurate normalization. For this reason, the selection and validation of the reference genes were among the most crucial steps in the setting up of this RTqPCR (Vandesompele et al., 2002; Bustin et al., 2009; Köhsler et al., 2020). This indicated two new suitable genes for gene expression studies in papaya fruit: $H 1$ and $t u b$. In this papaya fruit investigation, and independent of the treatments used in this study, these genes showed greater stability than $18 S$ rRNA, as suggested by Zhu et al. (2012), and the tuf gene. 


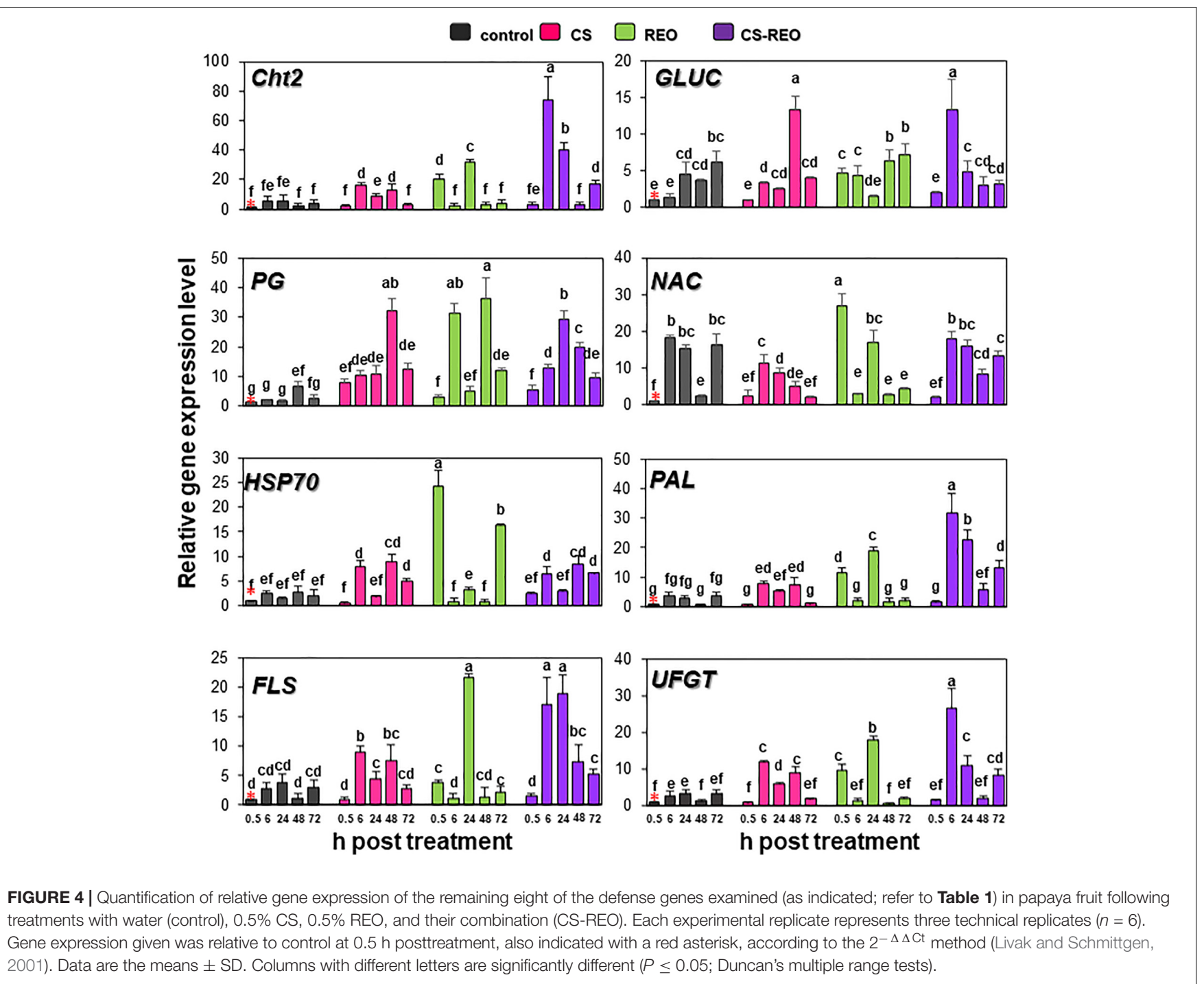

Based on this transcript analysis, this study showed that both the $0.5 \%$ CS and $0.5 \%$ REO treatments affected gene expression in the papaya fruits. However, according to the transcription of the individual genes analyzed in this study, some differences were seen. The jasmonic acid (JA)-responsive genes of JMT and LOX2 (Nakamura et al., 2011) were not affected in these papaya fruits by CS treatment, while they were involved in REO and CS-REO treatments. On the other hand, both CS and REO modulated the expression of genes linked to the SA pathway (i.e., $S A B P 2, P R-1$, and SNC1) and ET pathway (i.e., ET-2 and RAP2-13). Also, the $P R-5$ gene, which is linked to the SA pathway (Fu et al., 2012; Ali et al., 2018), was upregulated by REO treatment.

Many studies have indicated that the SA-mediated defense signaling pathway is important for activation of pathogen-associated molecular patterns that trigger immunity and for effector-triggered immunity, as well as for systemic acquired resistance (Jones and Dangl, 2006; Walters and Fountaine, 2009; Spoel and Dong, 2012). As well as the SAmediated defense signaling pathways are indicated as linked to biotrophic pathogen infection, the jasmonate/ET pathways are indicated as involved with regulators of stress responses against necrotrophic fungi (Wasternack and Hause, 2013), and induction of volatile compounds in response to insect herbivores (Rodriguez-Saona et al., 2013) and during abiotic stress (Wang et al., 2020). However, investigations carried out in recent years have shown the complexity of the plant regulatory network against stress. Indeed, cross talk between the SA-dependent, JA-dependent, and ET-dependent signaling pathways is believed to be involved in the fine-tuning of the defense reaction, to lead to the activation of an optimal mix of defense responses to resist any particular pathogen (Pieterse et al., 2009; Jia et al., 2018). In support of this, a previous study showed that oregano EO can trigger the plant's innate immune system that involves SA, JA, and ET synthesis and signaling, with the activation of PR proteins and phytoalexin synthesis (Rienth et al., 2019).

However, overall, our study showed that both CS and REO, and their combination CS-REO, can trigger signaling defense mechanisms to induce genes involved in phenylpropanoid 
biosynthesis and in cell wall metabolism, which demonstrates key roles for both secondary metabolite and cell wall genes in postharvest defense pathways (Landi et al., 2014, 2017; XocaOrozco et al., 2019; Zhang et al., 2020).

The present study underlines the involvement of genes linked to heat stress tolerance and cellular apoptotic change, in terms of NAC and HSP70 strongly upregulated in the early phase after REO treatment, while mainly for NAC gene, downregulation and /or unaffected gene expression was observed according to the other treatments. Part of the core of the data presented here is the difference detected between the CS and REO treatments according to activation times. The CS treatment affected gene expression mainly after 24 and $48 \mathrm{hpt}$, while the REO treatment strongly upregulated the gene transcripts earlier, at $0.5 \mathrm{hpt}$, then generally the gene expression drastically decreased at $6 \mathrm{hpt}$, then increased again mainly at $24 \mathrm{hpt}$, but to a lesser extent. In both cases, changes in gene expression over time are not surprising, given that gene expression is a complex stochastic process that represents the combination of numerous enzymatic reactions with unknown cell variables (Dal Co et al., 2017; Park et al., 2018). These changes in gene expression have been proposed to occur as the result of an optimization process, due to a trade-off between speed and cost (to the cell) of transcript production (Zaslaver et al., 2004). Also, the changes in gene expression might be linked to adaptation to the changes in stress (Koch and Guillaume, 2020). The present study suggests that these differences in gene expression over time can be correlated to the different natures of these two compounds, CS and REO. EOs are volatile, thermolabile, and unstable, which results in natural fluctuations in their components and compositions. They are highly reactive substances, and their antimicrobial activities might be impaired by changes in $\mathrm{pH}$ or temperature (Turek and Stintzing, 2013). On the other hand, CS has excellent film-forming properties, which will provide a mechanical barrier for the control of the respiration rate and decrease the loss of volatiles. The highly reactive volatile EOs can thus be stabilized and incorporated into the biodegradable, nontoxic CS, to produce transparent elastic films that can improve the effectiveness of their postharvest actions. This additive effect was evident in the gene expression patterns. Indeed, the genes analyzed after the CS-REO treatment generally showed greatly increased expression levels starting at $6 \mathrm{hpt}$, rather than at $0.5 \mathrm{hpt}$, as observed after the REO treatment. This might be due to the encapsulation of REO within the CS emulsion. Then, later on after the CS-REO treatment (i.e., beyond $6 \mathrm{hpt}$ ), for most of the genes, the expression levels were maintained relatively high for longer. This was seen for genes linked to the phenylpropanoid pathway, as PAL, FLS, and UFGT, as well as for genes involved in the signaling pathways that regulate plant defense, as SABP2, SNC1, M-JA, LOX2, ETR-2, and RAP2-13, but not for genes more closely with abiotic stresses such as NAC and HSP70, which suggests greater control of the cell stress by CS. This shows that the increase in the effectiveness of the disease control was associated with a broader and constant physiological change in the levels of the gene transcripts with roles in the induction of postharvest defense responses.

\section{CONCLUSION}

This study initially confirms that the incorporation of REO into the edible CS coating improves the control of postharvest decay of papaya fruit compared to the use of these treatments individually. For the first time, the main molecular mechanism in the triggering of defense pathways linked to the CS-REO combination is also indicated, as compared to their application. Indeed, CS largely showed effects on genes involved in the regulation of plant defense at $6 \mathrm{hpt}$, while REO showed strong induction of overexpression in the early phase, at $0.5 \mathrm{hpt}$. The CS-REO treatment also demonstrated additive actions on gene expression in these papaya fruits. This was supported by the delay in gene upregulation for CS-REO compared with REO, from 0.5 to $6 \mathrm{hpt}$, and kept longer over time. Indeed, this effect might be associated with CS such that it incorporates the volatile substances of the rue oil, and then releases them more slowly, to improve the regulation of cell stress.

This study thus represents an important first step in our better understanding of the molecular mechanisms involved in the combined effects of CS and EOs for postharvest control of fruit diseases. Similar studies are important for the control of postharvest decay, to suggest new strategies for induction of defense reactions in plants, and their possible use for the production of new active biological preparations.

\section{DATA AVAILABILITY STATEMENT}

The raw data supporting the conclusions of this article will be made available by the authors, without undue reservation.

\section{AUTHOR CONTRIBUTIONS}

LL and YP-R: methodology, statistical analysis, software, and writing-review and editing. LL, YP-R, CC-L, and GR: conceptualization, design of the study, and review and editing of the manuscript. CC-L and GR: supervision, project administration, and funding acquisition. All authors have read and agreed to the published version of the manuscript.

\section{FUNDING}

The authors acknowledge the financial support provided by the Marche Polytechnic University (PRIMA 2019 Project StopMedWaste), Euphresco BasicS project, and University of Teramo.

\section{ACKNOWLEDGMENTS}

We gratefully thank Xiaomeng Guo and Simone Piancatelli for their appreciated technical assistance. 


\section{REFERENCES}

Ahn, S.-G., Kim, S.-A., Yoon, J.-H., and Vacratsis, P. (2005). Heat-shock cognate 70 is required for the activation of heat-shock factor 1 in mammalian cells. Biochem. J. 392, 145-152. doi: 10.1042/BJ20050412

Ali, A., Mohamed, M. T. M., and Siddiqui, Y. (2012). Control of anthracnose by chitosan through stimulation of defence-related enzymes in Eksotika II papaya (Carica papaya L.) fruit. J. Biol. Life Sci. 3, 114-126. doi: 10.5296/jbls.v3i1. 1306

Ali, S., Ganai, B. A., Kamili, A. N., Bhat, A. A., Mir, Z. A., Bhat, J. A., et al. (2018). Pathogenesis-related proteins and peptides as promising tools for engineering plants with multiple stress tolerance. Microbiol. Res. 212, 29-37. doi: 10.1016/j. micres.2018.04.008

Alonso-Gato, M., Astray, G., Mejuto, J. C., and Simal-Gandara, J. (2021). Essential oils as antimicrobials in crop protection. Antibiotics 10:34. doi: 10.3390/ antibiotics 10010034

Banani, H., Olivieri, L., Santoro, K., Garibaldi, A., Gullino, M. L., and Spadaro, D. (2018). Thyme and savory essential oil efficacy and induction of resistance against Botrytis cinerea through priming of defense responses in apple. Foods 7:11. doi: 10.3390/foods7020011

Bannenberg, G., Martínez, M., Hamberg, M., and Castresana, C. (2009). Diversity of the enzymatic activity in the lipoxygenase gene family of Arabidopsis thaliana. Lipids 44, 85-95. doi: 10.1007/s11745-0083245-7

Batista, D., de, V. S., Reis, R. C., Almeida, J. M., Rezende, B., Bragança, C. A. D., et al. (2020). Edible coatings in post-harvest papaya: impact on physicalchemical and sensory characteristics. J. Food Sci. Technol. 57, 274-281. doi: 10.1007/s13197-019-04057-1

Brishti, F. H., Misir, J., and Sarker, A. (2013). Effect of biopreservatives on storage life of papaya (Carica papaya L.). Int. J. Food Stud. 2, 126-132. doi: 10.7455/ijfs/ 2.1.2013.a10

Bustin, S. A., Benes, V., Garson, J. A., Hellemans, J., Huggett, J., Kubista, M., et al. (2009). The MIQE guidelines: minimum information for publication of quantitative real-time PCR experiments. Clin. Chem. 55, 611-622. doi: 10.1373/ clinchem.2008.112797

Coqueiro, D. S. O., de Souza, A. A., Takita, M. A., Rodrigues, C. M., Kishi, L. T., and Machado, M. A. (2015). Transcriptional profile of sweet orange in response to chitosan and salicylic acid. BMC Genomics. 16:288. doi: 10.1186/s12864-0151440-5

Dal Co, A., Cosentino Lagomarsino, M., Caselle, M., and Osella, M. (2017). Stochastic timing in gene expression for simple regulatory strategies. Nucleic Acids Res. 45, 1069-1078. doi: 10.1093/nar/gkw1235

de Oliveira, K. ÁR., da Conceição, M. L., de Oliveira, S. P. A., dos Santos Lima, M., de Sousa Galvão, M., Madruga, M. S., et al. (2020). Postharvest quality improvements in mango cultivar Tommy Atkins by chitosan coating with Mentha piperita L. essential oil. J. Hortic. Sci. Biotechnol. 95, 260-272. doi: 10.1080/14620316.2019.1664338

Donadu, M. G., Peralta-Ruiz, Y., Usai, D., Maggio, F., Molina-Hernandez, J. B., Rizzo, D., et al. (2021). Colombian essential oil of Ruta graveolens against nosocomial antifungal resistant Candida strains. J. Fungi 7:383. doi: 10.3390/ jof7050383

Droby, S., and Wisniewski, M. (2018). The fruit microbiome: a new frontier for postharvest biocontrol and postharvest biology. Postharvest Biol. Technol. 140, 107-112. doi: 10.1016/j.postharvbio.2018.03.004

Duan, C., Meng, X., Meng, J., Khan, I. H., Dai, L., Khan, A., et al. (2019). Chitosan as a preservative for fruits and vegetables: a review on chemistry and antimicrobial properties. J. Bioresour. Bioprod. 4, 11-21. doi: 10.21967/jbb.v4i1. 189

El-Kereamy, A., El-Sharkawy, I., Ramamoorthy, R., Taheri, A., Errampalli, D., Kumar, P., et al. (2011). Prunus domestica pathogenesis-related protein-5 activates the defense response pathway and enhances the resistance to fungal infection. PLoS One 6:e17973. doi: 10.1371/journal.pone.0017973

Elshamy, S., Khadizatul, K., Uemura, K., Nakajima, M., and Neves, M. A. (2021). Chitosan-based film incorporated with essential oil nanoemulsion foreseeing enhanced antimicrobial effect. J. Food Sci. Technol. 58, 3314-3327. doi: 10.1007/ s13197-020-04888-3

Feliziani, E., Landi, L., and Romanazzi, G. (2015). Preharvest treatments with chitosan and other alternatives to conventional fungicides to control postharvest decay of strawberry. Carbohydr. Polym. 132, 111-117. doi: 10.1016 j.carbpol.2015.05.078

Food and Agricultural Organization of the United Nations (2020). Medium-Term Outlook: Prospects for Global Production and Trade in Bananas and Tropical Fruits 2019 to 2028. Rome: Food and Agricultural Organization of the United Nations.

Fu, Z. Q., Yan, S., Saleh, A., Wang, W., Ruble, J., Oka, N., et al. (2012). NPR3 and NPR4 are receptors for the immune signal salicylic acid in plants. Nature 486, 228-232. doi: 10.1038/nature11162

Gao, L., Wang, S., Li, X.-Y., Wei, X.-J., Zhang, Y.-J., Wang, H.-Y., et al. (2015). Expression and functional analysis of a pathogenesis-related protein 1 gene, TcLr19PR1, involved in wheat resistance against leaf rust fungus. Plant Mol. Biol. Report. 33, 797-805. doi: 10.1007/s11105-014-0790-5

García, J. M., Posé, S., Muñoz-Blanco, J., Quesada, M. A., and Mercado, J. A. (2009). The polygalacturonase FaPG1 gene plays a key role in strawberry fruit softening. Plant Signal. Behav. 4, 766-768. doi: 10.1104/pp.109.138297

González-Locarno, M., Maza Pautt, Y., Albis, A., Florez López, E., and Grande Tovar, D. C. (2020). Assessment of chitosan-rue (Ruta graveolens L.) essential oil-based coatings on refrigerated cape gooseberry (Physalis peruviana L.) quality. Appl. Sci. 10:2684. doi: 10.3390/app10082684

Grande Tovar, C. D., Delgado-Ospina, J., Navia Porras, D. P., Peralta-Ruiz, Y., Cordero, A. P., Castro, J. I., et al. (2019). Colletotrichum gloesporioides inhibition in situ by chitosan-Ruta graveolens essential oil coatings: effect on microbiological, physicochemical, and organoleptic properties of guava (Psidium guajava L.) during room temperature storage. Biomolecules 9:399. doi: 10.3390/biom9090399

Grande-Tovar, C. D., Chaves-Lopez, C., Serio, A., Rossi, C., and Paparella, A. (2018). Chitosan coatings enriched with essential oils: effects on fungi involve in fruit decay and mechanisms of action. Trends Food Sci. Technol. 78, 61-71. doi: 10.1016/j.tifs.2018.05.019

Gunathilake, D. M. C. C., Tiwari, A. K., and Kahandawala, K. A. T. (2018). Efficacy of washing treatment for extending the post-harvest shelf-life of papaya (Carica papaya). Int. J. Chem. Stud. 6, 2173-2177. doi: 10.22271/chemi.2018.v6.i4ai.05

Hammerbacher, A., Kandasamy, D., Ullah, C., Schmidt, A., Wright, L. P., and Gershenzon, J. (2019). Flavanone-3-hydroxylase plays an important role in the biosynthesis of spruce phenolic defenses against bark beetles and their fungal associates. Front. Plant Sci. 10:208. doi: 10.3389/fpls.2019.00208

Hernández-Ibáñez, A., Bautista-Baños, S., and Gutiérrez-Martínez, P. (2013). "Potential of Chitosan for Controlling Crown rot Disease of Banana (Musa acuminata) Fruit cv.'Enano gigante.,' in Advances in Science, Biotechnol Safety Foods-AMECA. México: Asociación Mexicana de Ciencia de los Alimentos A.C, 129-136.

Hossain, M. A., Noh, H.-N., Kim, K.-I., Koh, E.-J., Wi, S.-G., Bae, H.-J., et al. (2010). Mutation of the chitinase-like protein-encoding AtCTL2 gene enhances lignin accumulation in dark-grown Arabidopsis seedlings. J. Plant Physiol. 167, 650-658. doi: 10.1016/j.jplph.2009.12.001

Hou, J., Zhang, J., Zhang, B., Jin, X., Zhang, H., and Jin, Z. (2020). Transcriptional analysis of metabolic pathways and regulatory mechanisms of essential oil biosynthesis in the leaves of Cinnamomum camphora (L.) Presl. Front. Genet. 11:1386. doi: 10.3389/fgene.2020.598714

Hu, C., Gong, Y., Jin, S., and Zhu, Q. (2011). Molecular analysis of a UDP-glucose: flavonoid 3-O-glucosyltransferase (UFGT) gene from purple potato (Solanum tuberosum). Mol. Biol. Rep. 38, 561-567. doi: 10.1007/s11033-010-0141-Z

Huang, X., Lao, Y., Pan, Y., Chen, Y., Zhao, H., Gong, L., et al. (2021). Synergistic antimicrobial effectiveness of plant essential oil and its application in seafood preservation: a review. Molecules 26:307. doi: 10.3390/molecules 26020307

Janke, C., and Magiera, M. M. (2020). The tubulin code and its role in controlling microtubule properties and functions. Nat. Rev. Mol. Cell Biol. 21, 307-326. doi: 10.1038/s41580-020-0214-3

Jarisarapurin, W., Sanrattana, W., Chularojmontri, L., Kunchana, K., and Wattanapitayakul, S. K. (2019). Antioxidant properties of unripe Carica papaya fruit extract and its protective effects against endothelial oxidative stress. Evid. Based Complement. Alternat. Med. 2019:4912631. doi: 10.1155/2019/4912631

Jia, X., Zeng, H., Wang, W., Zhang, F., and Yin, H. (2018). Chitosan oligosaccharide induces resistance to Pseudomonas syringae pv. tomato DC3000 in Arabidopsis thaliana by activating both salicylic acid-and jasmonic acidmediated pathways. Mol. Plant Microbe Interact. 31, 1271-1279. doi: 10.1094/ MPMI-03-18-0071-R 
Jones, J., and Dangl, J. (2006). The plant immune system. Nature 444, 323-329. doi: 10.1038 /nature 05286

Kim, D. S., and Hwang, B. K. (2014). An important role of the pepper phenylalanine ammonia-lyase gene (PAL1) in salicylic acid-dependent signalling of the defence response to microbial pathogens. J. Exp. Bot. 65, 2295-2306. doi: 10. 1093/jxb/eru109

Koch, E. L., and Guillaume, F. (2020). Additive and mostly adaptive plastic responses of gene expression to multiple stress in Tribolium castaneum. PLoS Genet. 16:e1008768. doi: 10.1371/journal.pgen.1008768

Köhsler, M., Leitsch, D., Müller, N., and Walochnik, J. (2020). Validation of reference genes for the normalization of RT-qPCR gene expression in Acanthamoeba spp. Sci. Rep. 10:10362. doi: 10.1038/s41598-020-67035-0

Landi, L., Angelini, R. M. D. M., Pollastro, S., Feliziani, E., Faretra, F., and Romanazzi, G. (2017). Global transcriptome analysis and identification of differentially expressed genes in strawberry after preharvest application of benzothiadiazole and chitosan. Front. Plant Sci. 8:235. doi: 10.3389/fpls.2017. 00235

Landi, L., Feliziani, E., and Romanazzi, G. (2014). Expression of defense genes in strawberry fruits treated with different resistance inducers. J. Agric. Food Chem. 62, 3047-3056. doi: 10.1021/jf404423x

Lima Oliveira, P. D., de Oliveira, K. ÁR., Vieira, W. A., dos, S., Câmara, M. P. S., and de Souza, E. L. (2018). Control of anthracnose caused by Colletotrichum species in guava, mango and papaya using synergistic combinations of chitosan and Cymbopogon citratus (D.C. ex Nees) Stapf. essential oil. Int. J. Food Microbiol. 266, 87-94. doi: 10.1016/j.ijfoodmicro.2017.11.018

Livak, K. J., and Schmittgen, T. D. (2001). Analysis of relative gene expression data using real-time quantitative PCR and the $2-\Delta \Delta$ CT method. Methods 25 , 402-408. doi: 10.1006/meth.2001.1262

Lv, X., Lan, S., Guy, K. M., Yang, J., Zhang, M., and Hu, Z. (2016). Global expressions landscape of NAC transcription factor family and their responses to abiotic stresses in Citrullus lanatus. Sci. Rep. 6:30574. doi: 10.1038/srep30574

Ma, Z., Yang, L., Yan, H., Kennedy, J. F., and Meng, X. (2013). Chitosan and oligochitosan enhance the resistance of peach fruit to brown rot. Carbohydr. Polym. 94, 272-277. doi: 10.1016/j.carbpol.2013.01.012

McKinney, H. H. (1923). Influence of soil temperature and moisture on infection of wheat seedlings by Helmintosporium sativum. J. Agric. Res. 26, 195-218.

Munhuweyi, K., Caleb, O. J., Lennox, C. L., van Reenen, A. J., and Opara, U. L. (2017). In-vitro and in-vivo antifungal activity of chitosan-essential oils against pomegranate fruit pathogens. Postharvest Biol. Technol. 129, 9-22. doi: 10.1016/ j.postharvbio.2017.03.002

Mutjaba, M., Morsi, R., Kerch, G., Elsabee, M., Kaya, M., Labidi, J., et al. (2019). Current advancements in chitosan-based film production for food technology: a review. Int. J. Biol. Macromol. 121, 889-904. doi: 10.1016/j.ijbiomac.2018.10. 109

Nair, M. S., Tomar, M., Punia, S., Kukula-Koch, W., and Kumar, M. (2020). Enhancing the functionality of chitosan-and alginate-based active edible coatings/films for the preservation of fruits and vegetables: a review. Int. J. Biol. Macromol. 164, 304-320. doi: 10.1016/j.ijbiomac.2020.07.083

Nakamura, Y., Mithöfer, A., Kombrink, E., Boland, W., Hamamoto, S., Uozumi, N., et al. (2011). 12-Hydroxyjasmonic acid glucoside is a COI1-JAZ-independent activator of leaf-closing movement in Samanea saman. Plant Physiol. 155, 1226-1236. doi: 10.1104/pp.110.168617

Nazzaro, F., Fratianni, F., Coppola, R., and De Feo, V. (2017). Essential oils and antifungal activity. Pharmaceuticals 10:86. doi: 10.3390/ph10040086

O’Malley, R. C., Rodriguez, F. I., Esch, J. J., Binder, B. M., O’Donnell, P., Klee, H. J., et al. (2005). Ethylene-binding activity, gene expression levels, and receptor system output for ethylene receptor family members from Arabidopsis and tomato. Plant J. 41, 651-659. doi: 10.1111/j.1365-313X.2004.02331.x

Obianom, C., Romanazzi, G., and Sivakumar, D. (2019). Effects of chitosan treatment on avocado postharvest diseases and expression of phenylalanine ammonia-lyase, chitinase and lipoxygenase genes. Postharvest Biol. Technol. 147, 214-221. doi: 10.1016/j.postharvbio.2018.10.004

Park, S. J., Song, S., Yang, G.-S., Kim, P. M., Yoon, S., Kim, J.-H., et al. (2018). The chemical fluctuation theorem governing gene expression. Nat. Commun. 9:297. doi: 10.1038/s41467-017-02737-0

Park, S.-W., Liu, P.-P., Forouhar, F., Vlot, A. C., Tong, L., Tietjen, K., et al. (2009). Use of a synthetic salicylic acid analog to investigate the roles of methyl salicylate and its esterases in plant disease resistance. J. Biol. Chem. 284, 7307-7317.

Parven, A., Sarker, M. R., Megharaj, M., and Md. Meftaul, I. (2020). Prolonging the shelf life of papaya (Carica papaya L.) using aloe vera gel at ambient temperature. Sci. Hortic. 265:109228. doi: 10.1016/j.scienta.2020.109228

Paul, M. V., Iyer, S., Amerhauser, C., Lehmann, M., van Dongen, J. T., and Geigenberger, P. (2016). Oxygen sensing via the ethylene response transcription factor RAP2.12 affects plant metabolism and performance under both normoxia and hypoxia. Plant Physiol. 172, 141-153. doi: 10.1104/pp.16. 00460

Peralta-Ruiz, Y., Grande Tovar, C., Sinning-Mangonez, A., Coronell, E. A., Marino, M. F., and Chaves-Lopez, C. (2020b). Reduction of postharvest quality loss and microbiological decay of tomato "chonto" (Solanum lycopersicum L.) using chitosan-essential oil-based edible coatings under low-temperature storage. Polymers 12:1822. doi: 10.3390/polym12081822

Peralta-Ruiz, Y., Grande Tovar, C., Sinning-Mangonez, A., Bermont, D., Pérez Cordero, A., Paparella, A., et al. (2020a). Colletotrichum gloeosporioides inhibition using chitosan-Ruta graveolens L essential oil coatings: studies in vitro and in situ on Carica papaya fruit. Int. J. Food Microbiol. 326:108649. doi: 10.1016/j.ijfoodmicro.2020.108649

Peralta-Ruiz, Y., Grande-Tovar, C. D., Navia Porras, D. P., Sinning-Mangonez, A., Delgado-Ospina, J., González-Locarno, M., et al. (2021). Packham's triumph pears (Pyrus communis L.) post-harvest treatment during cold storage based on chitosan and rue essential oil. Molecules 26:725. doi: 10.3390/ molecules 26030725

Pieterse, C. M. J., Leon-Reyes, A., Van der Ent, S., and Van Wees, S. C. M. (2009). Networking by small-molecule hormones in plant immunity. Nat. Chem. Biol. 5, 308-316. doi: 10.1038/nchembio. 164

Pisoschi, A. M., Pop, A., Georgescu, C., Turcuş, V., Olah, N. K., and Mathe, E. (2018). An overview of natural antimicrobials role in food. Eur. J. Med. Chem. 143, 922-935. doi: 10.1016/j.ejmech.2017.11.095

Poltronieri, P., and Hong, Y. (2015). Applied Plant Genomics and Biotechnology. Sawston: Woodhead Publishing.

Rahman, M. H., Shovan, L. R., Hjeljord, L. G., Aam, B. B., Eijsink, V. G. H., Sørlie, M., et al. (2014). Inhibition of fungal plant pathogens by synergistic action of chito-oligosaccharides and commercially available fungicides. PLoS One 9:e93192. doi: 10.1371/journal.pone.0093192

Rajestary, R., Landi, L., and Romanazzi, G. (2021). Chitosan and postharvest decay of fresh fruit: meta-analysis of disease control and antimicrobial and eliciting activities. Compr. Rev. Food Sci. Food Saf. 20, 563-582. doi: 10.1111/1541-4337. 12672

Rhee, S. G., Kang, S. W., Chang, T., Jeong, W., and Kim, K. (2001). Peroxiredoxin, a novel family of peroxidases. IUBMB Life 52, 35-41. doi: 10. 1080/15216540252774748

Rienth, M., Crovadore, J., Ghaffari, S., and Lefort, F. (2019). Oregano essential oil vapour prevents Plasmopara viticola infection in grapevine (Vitis Vinifera) and primes plant immunity mechanisms. PLoS One 14:e222854. doi: 10.1371/ journal.pone.0222854

Rodríguez, J., Martín, M. J., Ruiz, M. A., and Clares, B. (2016). Current encapsulation strategies for bioactive oils: from alimentary to pharmaceutical perspectives. Food Res. Int. 83, 41-59. doi: 10.1016/j.foodres.2016. 01.032

Rodriguez-Saona, C., Polashock, J., and Malo, E. (2013). Jasmonate-mediated induced volatiles in the American cranberry, Vaccinium macrocarpon: from gene expression to organismal interactions. Front. Plant Sci. 4:115. doi: 10.3389/ fpls.2013.00115

Romanazzi, G., Feliziani, E., and Sivakumar, D. (2018). Chitosan, a biopolymer with triple action on postharvest decay of fruit and vegetables: eliciting, antimicrobial and film-forming properties. Front. Microbiol. 9:2745. doi: 10 3389/fmicb.2018.02745

Romanazzi, G., Feliziani, E., Santini, M., and Landi, L. (2013). Effectiveness of postharvest treatment with chitosan and other resistance inducers in the control of storage decay of strawberry. Postharvest Biol. Technol. 75, 24-27. doi: 10. 1016/j.postharvbio.2012.07.007

Santamaría, F., Sauri, E., Espadas, F., Díaz, R., Larqué, A., and Santamaría, J. (2009). Postharvest ripening and maturity indices for maradol papaya. Interciencia 34 , 583-588. 
Sasikumar, A. N., Perez, W. B., and Kinzy, T. G. (2012). The many roles of the eukaryotic elongation factor 1 complex. Wiley Interdiscip. Rev. RNA 3, 543-555. doi: 10.1002/wrna.1118

Seo, H. S., Song, J. T., Cheong, J.-J., Lee, Y.-H., Lee, Y.-W., Hwang, I., et al. (2001). Jasmonic acid carboxyl methyltransferase: a key enzyme for jasmonateregulated plant responses. Proc. Natl. Acad. Sci. U.S.A. 98, 4788-4793. doi: 10.1073/pnas.081557298

Sharifi-Rad, J., Sureda, A., Tenore, G., Daglia, M., Sharifi-Rad, M., Valussi, M., et al. (2017). Biological activities of essential oils: from plant chemoecology to traditional healing systems. Molecules 22:70. doi: 10.3390/molecules2201 0070

Sivakumar, D., and Bautista-Baños, S. (2014). A review on the use of essential oils for postharvest decay control and maintenance of fruit quality during storage. Crop Prot. 64, 27-37. doi: 10.1016/j.cropro.2014. 05.012

Sivakumar, D., and Romanazzi, G. (2019). "Essential oils improve postharvest quality and control postharvest decay of tropical, subtropical and temperate fruits," in Postharvest Pathology of Fresh Horticultural Produce, eds L. Palou and J. L. Smilanick (Boca Raton, FL: CRC PRESS), 659-676.

Spoel, S. H., and Dong, X. (2012). How do plants achieve immunity? Defence without specialized immune cells. Nat. Rev. Immunol. 12, 89-100. doi: 10.1038/ nri3141

Thomas, B. R., Inouhe, M., Simmons, C. R., and Nevins, D. J. (2000). Endo-1, 3; 1, 4 - $\beta$-glucanase from coleoptiles of rice and maize: role in the regulation of plant growth. Int. J. Biol. Macromol. 27, 145-149. doi: 10.1016/s0141-8130(00)00 $110-0$

Turek, C., and Stintzing, F. C. (2013). Stability of essential oils: a review. Compr. Rev. food Sci. Food Saf. 12, 40-53. doi: 10.1111/1541-4337. 12006

Valencia-Chamorro, S. A., Palou, L., del Río, M. A., and Pérez-Gago, M. B. (2011). Antimicrobial edible films and coatings for fresh and minimally processed fruits and vegetables: a review. Crit. Rev. Food Sci. Nutr. 51, 872-900. doi: 10.1080/ 10408398.2010.485705

Vandesompele, J., De Preter, K., Pattyn, F., Poppe, B., Van Roy, N., De Paepe, A., et al. (2002). Accurate normalization of real-time quantitative RTPCR data by geometric averaging of multiple internal control genes. Genome Biol. 3:RESEARCH0034. doi: 10.1186/gb-2002-3-7-research 0034

Walters, D. R., and Fountaine, J. M. (2009). Practical application of induced resistance to plant diseases: an appraisal of effectiveness under field conditions. J. Agric. Sci. 147, 523-535. doi: 10.1017/S0021859609008806

Wang, J., Song, L., Gong, X., Xu, J., and Li, M. (2020). Functions of jasmonic acid in plant regulation and response to abiotic stress. Int. J. Mol. Sci. 21:1446. doi: $10.3390 / \mathrm{ijms} 21041446$

Wasternack, C., and Hause, B. (2013). Jasmonates: biosynthesis, perception, signal transduction and action in plant stress response, growth and development. an update to the 2007 review in annals of botany. Ann. Bot. 111, 1021-1058. doi: $10.1093 / \mathrm{aob} / \mathrm{mct} 067$
Woodcock, C. L., Skoultchi, A. I., and Fan, Y. (2006). Role of linker histone in chromatin structure and function: $\mathrm{H} 1$ stoichiometry and nucleosome repeat length. Chromosom. Res. 14, 17-25. doi: 10.1007/s10577-005-1024-3

Xoca-Orozco, L. -Á, Aguilera-Aguirre, S., Vega-Arreguín, J., Acevedo-Hernández, G., Tovar-Pérez, E., Stoll, A., et al. (2019). Activation of the phenylpropanoid biosynthesis pathway reveals a novel action mechanism of the elicitor effect of chitosan on avocado fruit epicarp. Food Res. Int. 121, 586-592. doi: 10.1016/j. foodres.2018.12.023

Yuan, G., Chen, X., and Li, D. (2016). Chitosan films and coatings containing essential oils: the antioxidant and antimicrobial activity, and application in food systems. Food Res. Int. 89, 117-128. doi: 10.1016/j.foodres.2016.10.004

Zaslaver, A., Mayo, A. E., Rosenberg, R., Bashkin, P., Sberro, H., Tsalyuk, M., et al. (2004). Just-in-time transcription program in metabolic pathways. Nat. Genet. 36, 486-491. doi: 10.1038/ng1348

Zhang, D., Gan, R., Zhang, J., Farha, A. K., Li, H., Zhu, F., et al. (2020). Antivirulence properties and related mechanisms of spice essential oils: a comprehensive review. Compr. Rev. Food Sci. Food Saf. 19, 1018-1055. doi: 10.1111/1541-4337.12549

Zhang, Z., Zhao, P., Zhang, P., Su, L., Jia, H., Wei, X., et al. (2020). Integrative transcriptomics and metabolomics data exploring the effect of chitosan on postharvest grape resistance to Botrytis cinerea. Postharvest Biol. Technol. 167:111248. doi: 10.1016/j.postharvbio.2020.111248

Zhu, X., Li, X., Chen, W., Chen, J., Lu, W., Chen, L., et al. (2012). Evaluation of new reference genes in papaya for accurate transcript normalization under different experimental conditions. PLoS One 7:e44405. doi: 10.1371/journal. pone.0044405

Zhu, Z., Xu, F., Zhang, Y., Cheng, Y. T., Wiermer, M., Li, X., et al. (2010). Arabidopsis resistance protein $\mathrm{SNC1}$ activates immune responses through association with a transcriptional corepressor. Proc. Natl. Acad. Sci. U.S.A. 107, 13960-13965. doi: 10.1073/pnas.1002828107

Conflict of Interest: The authors declare that the research was conducted in the absence of any commercial or financial relationships that could be construed as a potential conflict of interest.

Publisher's Note: All claims expressed in this article are solely those of the authors and do not necessarily represent those of their affiliated organizations, or those of the publisher, the editors and the reviewers. Any product that may be evaluated in this article, or claim that may be made by its manufacturer, is not guaranteed or endorsed by the publisher.

Copyright (C) 2021 Landi, Peralta-Ruiz, Chaves-López and Romanazzi. This is an open-access article distributed under the terms of the Creative Commons Attribution License (CC BY). The use, distribution or reproduction in other forums is permitted, provided the original author(s) and the copyright owner(s) are credited and that the original publication in this journal is cited, in accordance with accepted academic practice. No use, distribution or reproduction is permitted which does not comply with these terms. 